\title{
Poland's Rule of Law Crisis: Some Thoughts
}

\section{Marcin Matczak ${ }^{1}$}

Published online: 5 November 2019

(c) The Author(s) 2019

This year, Poland celebrates the 30th anniversary of the fall of the Communist regime. This represented a crucial victory for democracy over totalitarianism and was one of the most momentous events in Polish history. Unfortunately, however, recent political developments have put a damper on the celebration. With its sustained and unprecedented assault on the separation of powers and the independence of the judiciary, the current Polish government, which took office in November 2015, has forced people to reconsider their conviction that democracy and the rule of law are now so firmly entrenched that their impairment or subversion is beyond the capacity of any government, no matter how autocratic.

As a result of these developments, Poland, once a paradigm of a successful transition to democracy, has become a pariah. All the indications are that it may veer off the democratic path or even abandon it altogether. What brought the country to this point? Was it an internal flaw in a fragile democracy or irresistible external pressures? These questions have been asked many times over the last 4 years, but they have become even more burning now after the recent European Parliament elections. When an autocratic party with an avowedly anti-European mindset wins the popular vote, one knows that the problem is much deeper and much more pervasive than it appears, and that it is not only politicians who hold the rule of law in contempt, but the people.

Three possible explanations for the Polish crisis suggest themselves. First, Poland's transition to democracy was merely ostensible or at best superficial. Having had no genuine sovereignty for over two centuries, with the exception of the 22 years between the two world wars, Poland had neither the qualifications nor the experience to embrace democracy and the rule of law with complete cognizance and maturity. The country could be likened to a child wearing oversized shoes, and was therefore bound to collapse sooner or later. I have heard this explanation many times, mainly from foreign observers. I have always rejected it as condescending and patronizing.

When sixty thousand people take to the streets of Warsaw to defend a value as abstract as the separation of powers, it cannot be said that they do not understand

Marcin Matczak

marcinsmatczak@gmail.com

1 Warsaw, Poland 
the significance of the rule of law. And when thousands of men and women from all over Poland express their support for Supreme Court judges who are being forcibly removed from their posts, it cannot be said that Polish democracy is "immature". Our understanding of democracy and the rule of law is not in any way deficient or defective. Moreover, the crisis we face is by no means a purely domestic one. Its symptoms, as well as its underlying causes- to which I shall return-are far more universal.

Another explanation links the current crisis, not with the immaturity of democracy in Poland (or Central Europe in general), but with the specifics of the postcommunist transformation in the region. The transition from communism to a liberal democracy has not been equally beneficial to everyone-at least not in everyone's subjective estimation. Even though the standard of living has skyrocketed since 1989, whether and to what extent this transition has been a success is assessed very differently from one region to another, and even from one individual to another. The transition is adjudged by many to have been unjust, and it is not always clear whether their criterion is distributive or retributive injustice.

The most probable answer is both. After decades of enforced communist "equality", a great deal of inequality was abruptly introduced into many aspects of people's lives, and those who have benefited least from the economic transformation of the country feel cheated, and are inclined to blame their fate on the new distribution mechanisms. At the same time, many people continue to feel frustrated by the uneventfulness of the transition to democracy, and the lack of criminal investigations, let alone prosecutions, of communist politicians and officials. These people have never ceased to demand that the communists be punished and marginalized in the new Poland, and remain unshakeable in their belief that the Round Table negotiations of 1989 were a pact with the devil. The adroitness of those Polish leaders who managed to topple communism without shedding a drop of blood is seen by some as tantamount to treachery.

Therefore, when Law and Justice came to power and promised that both distributive and retributive justice would be done, those people supported it, even if the former adversely affects state finances, and the latter entails unlawfully removing "communist" judges from their posts. The simple, unassailable fact that the average Polish judge was only 12 years old when communism collapsed, and therefore could not have been an active communist, counts for nothing to enraged people feeding their frustration with a craving for vengeance. In effect, the dismantling of the rule of law, especially the unrelenting assault on the independence of the judiciary, can at least partially be attributed to an irrational need to settle accounts with the past. Sadly, this can only bode ill for Poland's future.

The third explanation for the ongoing crisis of democracy in Poland and for that country's failure to promote, protect and enforce the rule of law is to be found in far more universal and deep-seated causes. This crisis is not endemic to Poland; liberal democracy is in crisis everywhere. Nor is the crisis a natural consequence of inadequate institutional arrangements; it has its origins in the refusal to respect institutions. And this is not only a refusal on the part of opportunistic politicians resentful of having their power curtailed; it has broad societal acceptance, and (unbelievably) even support. As Martin Krygier has consistently argued, respect for the rule of law 
must reside in the hearts and minds of the general populace if it is to be anything more than lip service and the law is to function effectively.

The internet revolution has given people unprecedented access to information and increased their self-awareness, which-as we recall from the story of Adam and Eve being driven out of Eden-is not necessarily an unmitigated blessing. Today's constantly connected world seems more troubled than ever, and the media competition for our attention promotes bad-and often fake-news over mundane facts. This leads to insecurity, and insecurity leads to the Frommian escape from freedom. Liberal democracy, with its inherent reluctance to regulate people's lives and its strong underlying conviction that certain domains are the preserve of the individual and that the state has no business interfering in them, is considerably less attractive than it was 30 years ago. Strong, and often autocratic, leaders promise to solve people's problems and protect them from any and every internal and external threat. They provide the citizenry with ready-made axiological plans. And they are in the ascendancy. Insecure voters are increasingly disoriented in a world in which authority figures come across as indecisive, ineffectual, and often immoral. Thus, freedom is traded for security.

I see many parallels between the anti-rule-of-law movement and the anti-vaccination movement. Consider the motivation of people who refuse to vaccinate their children. At some point, they must have been told that vaccination is potentially dangerous on account of side-effects. They may think that this information about the side-effects of vaccination has been hidden from them, and that the internet has enabled them to discover the truth. The rule of law has its "side-effects" too, e.g. an independent judiciary can lead to unlimited discretionary powers, and ostensibly apolitical judges may in fact be very politically partisan. Again, the truth that judges are only human can be easily discovered nowadays.

"Discovering" the "truth" about side-effects may lead people to think that it has been purposely hidden from them by doctors and lawyers respectively. The result is insecurity, distrust and a determination to take control of the future of their children (vaccination) and their states (the rule of law).

A cost-benefit analysis next comes into play: if vaccination (and the rule of law) carries some risks, then these risks, as well as the benefits against which they are to be weighed, have to be determined and quantified. And this is by no means an easy task. If vaccination works, then nothing spectacular happens-children are healthy and simply live their lives. Similarly, when liberal democracy and the rule of law work properly, nothing spectacular happens. People live in peace, there are no tanks on the streets... life can even seem a little boring.

If the flaws are highlighted often enough, and the benefits are inconspicuous, then a cost-benefit analysis leads to the conclusion that neither vaccination, nor the rule of law are indispensable. Perhaps, the reasoning goes, if we stop vaccinating ourselves (and abandon the rule of law), nothing bad will happen, as nothing bad is happening now, and we will not have to worry about any side-effects.

The problem with this reasoning is obvious: nothing bad is happening now precisely because both vaccination and the rule of law are working as intended. We can thank them for eradicating e.g. measles and war, at least in the European Union, which has given this part of the world its longest ever period of continuous peace. If 
we stopped vaccinating ourselves and ceased to respect the rule of law, their protection mechanisms would cease to function, and the consequences would be far worse than any side-effects.

Like vaccination, the rule of law is a mechanism for ensuring long-term safety and well-being. When people lose patience, then politicians and public intellectuals who value the rule of law have a responsibility to clearly explain how these mechanisms work and why they are needed. They cannot communicate this in a way that is aggressive towards their political opponents. Aggression spreads fear, fear amplifies insecurity, and insecurity makes the apparent need to sacrifice freedom for safety even more imperative.

At the same time, liberal democracy needs to reinvent itself. The negative freedom, i.e. from coercion, on which it is based no longer suffices: people need great plans for their lives, and autocratic leaders are only too happy to provide them. Unless liberal democracy can propose a great plan of its own, it is doomed to obscurity. What is required is a broad plan for the future; a great vision which will provide people with a sense of control and guidance, give them tasks and show them clear purposes, and thereby offer hope that the world is heading in the right direction. These sorts of visions have been the specialty of autocracies, but the time has come for liberal democracy to produce one of its own. A vision that will be alluring, but at the same time promote respect for procedural justice and the rule of law. This vision cannot be local, because we need to protect freedom and the rule of law not only in Poland or Central Europe, but everywhere, because the crisis we face is universal not local.

Open Access This article is distributed under the terms of the Creative Commons Attribution 4.0 International License (http://creativecommons.org/licenses/by/4.0/), which permits unrestricted use, distribution, and reproduction in any medium, provided you give appropriate credit to the original author(s) and the source, provide a link to the Creative Commons license, and indicate if changes were made. 